\title{
Cytotoxic activity of proteins isolated from extracts of Corydalis cava tubers in human cervical carcinoma HeLa cells
}

\author{
Robert Nawrot ${ }^{1 *}$, Maria Wolun-Cholewa², Wojciech Bialas ${ }^{3}$, Danuta Wyrzykowska', Stanislaw Balcerkiewicz ${ }^{4}$ \\ Anna Gozdzicka-Jozefiak
}

\begin{abstract}
Background: Corydalis cava Schweigg. \& Koerte, the plant of numerous pharmacological activities, together with the studied earlier by our group Chelidonium majus L. (Greater Celandine), belong to the family Papaveraceae. The plant grows in Central and South Europe and produces the sizeable subterraneous tubers, empty inside, which are extremely resistant to various pathogen attacks. The Corydalis sp. tubers are a rich source of many biologically active substances, with the extensive use in European and Asian folk medicine. They have analgetic, sedating, narcotic, anti-inflammatory, anti-allergic and anti-tumour activities. On the other hand, there is no information about possible biological activities of proteins contained in Corydalis cava tubers.
\end{abstract}

Methods: Nucleolytic proteins were isolated from the tubers of C. cava by separation on a heparin column and tested for DNase activity. Protein fractions showing nucleolytic activity were tested for cytotoxic activity in human cervical carcinoma HeLa cells. Cultures of HeLa cells were conducted in the presence of three protein concentrations: 42,83 and $167 \mathrm{ng} / \mathrm{ml}$ during $48 \mathrm{~h}$. Viability of cell cultures was appraised using XTT colorimetric test. Protein fractions were separated and protein bands were excised and sent for identification by mass spectrometry (LC-ESI-MS/MS).

Results: The studied protein fractions showed an inhibiting effect on mitochondrial activity of HeLa cells, depending on the administered dose of proteins. The most pronounced effect was obtained with the highest concentration of the protein $(167 \mathrm{ng} / \mathrm{ml})-43.45 \pm 3 \%$ mitochondrial activity of HeLa cells were inhibited. Mass spectrometry results for the proteins of applied fractions showed that they contained plant defense- and pathogenesis-related (PR) proteins.

Conclusions: The cytotoxic effect of studied proteins toward HeLa cell line cells has been evident and dependent on increasing dose of the protein. The present study, most probably, represents the first investigations on the effect of purified PR proteins from tuber extracts of a pharmacologically active plant on cell lines.

\section{Background}

Plants from the family Papaveraceae are frequently used in traditional medicine as a remedy for treatment of several diseases. Such plants include Corydalis cava Schweigg. \& Koerte; syn. Corydalis bulbosa (L.) Pers. non (L.) DC. and Chelidonium majus L. studied earlier by our group (Greater Celandine). The two species are

\footnotetext{
* Correspondence: rnawrot@amu.edu.pl

'Department of Molecular Virology, Institute of Experimental Biology, Faculty of Biology, Adam Mickiewicz University, Umultowska 89, 61-614 Poznan, Poland

Full list of author information is available at the end of the article
}

closely related and belong to order Papaverales [1,2]. Milky sap as well as extracts of the whole Chelidonium majus plant has been used to treat papillae, warts, condylomae, which are a visible effect of human papilloma virus (HPV) infection. It has also been found that they have antimicrobial, antitumor, anti-inflammatory, antifungal, and fungistatic properties [3]. The tuber of Corydalis $s p$. contains isoquinoline alkaloids of apomorphine type, e.g. bulbocapnine, corydaline, which manifest analgetic, sedating and narcotic effects [4-7]. The plant has been used for the treatment of severe neurological
C Biomed Central

(C) 2010 Nawrot et al; licensee BioMed Central Ltd. This is an Open Access article distributed under the terms of the Creative Commons Attribution License (http://creativecommons.org/licenses/by/2.0), which permits unrestricted use, distribution, and reproduction in any medium, provided the original work is properly cited. 
disorders and mental diseases. It was also used in cases of asomnia, tension and anxiety conditions [7]. Some species of Corydalis are used in East Asia as analgetic drugs: in the traditional Chinese medicine, the species of Corydalis yanhusho was used to alleviate post-traumatic, colic, abdominal and menstrual pains [7]. Moreover, extracts of the same species showed anti-cancerous metastasis effect in vitro [8]. Anti-tumour activity of Corydalis species was also reported for Korean Corydalis turtschaninovii, which is effective for the treatment of inflammatory, allergic diseases and tumours [9]. Isoquinoline alkaloids contained in alcohol extracts of tubers in many species of Corydalis, affect metabolism of neurotransmitters [10]. Active compounds in such extracts include alkaloids, such as bulbocapnine, corydaline and corydine [11]. The similar curing properties of Chelidonium majus milky sap were attributed mainly to alkaloids, such as chelidonine, sanguinarine, berberine, coptosine, chelerythrine, and also several flavonoids and phenolic acids [12]. However, different findings show that all of them may be potentially toxic for human either alone or in combination $[13,14]$.

Our earlier studies have shown that biological activity of Chelidonium majus milky sap may be related to its protein content. The majority of the identified proteins can be linked to direct and indirect stress and defense reactions, e.g. against different pathogens [15-17]. We have recently discovered that purified plant proteins from Chelidonium majus milky sap with nucleolytic activity, which probably belong to pathogenesis-related (PR) protein family, are capable of inducing apoptosis in human cervical cancer HeLa cells [17].

Therefore, the objective of our study was to evaluate the effect of purified proteins from extracts of Corydalis cava tubers with nucleolytic activity on HeLa tumour cells and to identify the protein content of such purified fractions using tandem mass spectrometry.

\section{Methods}

\section{Plant material}

Corydalis cava plants were collected during 2007 and 2008 in the neighbourhood of Poznań, Poland, during flowering, in April. A voucher specimen was deposited at the Department of Molecular Virology, Faculty of Biology, Adam Mickiewicz University in Poznan, Poland.

\section{Protein extract}

The protein extract was prepared from tubers, dissolved in $0.1 \mathrm{M}$ Tris-Cl buffer, $\mathrm{pH}$ 8.0, containing $10 \%$ glycerol (extract : buffer ratio was $1: 1)$. The tuber extract $(50 \%$ $\mathrm{v} / \mathrm{v})$ samples were separated into a supernatant, and a pellet fraction, by centrifugation at $12000 \mathrm{rpm}$ for $20 \mathrm{~min}$ at $4^{\circ} \mathrm{C}$ as described in the protocol [16], with modifications. Supernatants were stored at $-20^{\circ} \mathrm{C}$ for further analysis. Protein concentration was determined according to Lowry et al. [18].

\section{Isolation and purification of proteins}

For isolation and purification of proteins, crude extracts from C. cava tubers collected in April were used. About $0.5-\mu$ g protein was loaded on HT Heparin column (GE Healthcare) $(0.7 \times 2.5 \mathrm{~cm})$ equilibrated with $0.1 \mathrm{M}$ Tris$\mathrm{HCl}, \mathrm{pH} 8.0,10 \%$ glycerol. The column was eluted with a linear gradient of 0 to $2 \mathrm{M} \mathrm{NaCl}$ in the same buffer. The absorbance at $280 \mathrm{~nm}$ and DNase activity of all fractions (volume $1 \mathrm{ml}$ ) were determined.

\section{Analysis by SDS-PAGE}

In order to verify the protein composition of chromatographic fractions, sodium dodecyl sulfate polyacrylamide gel electrophoresis (SDS-PAGE) was carried out in a slab mini-gel apparatus according to Laemmli 1970 [19], using $10 \%$ polyacrylamide as the separating gel and $5 \%$ polyacrylamide as the stacking gel. The proteins were reduced by heating them at $100^{\circ} \mathrm{C}$ in the presence of 2-mercaptoethanol for $5 \mathrm{~min}$. After SDS-PAGE, the gels were fixed and stained with silver according to Shevchenko et al. [20].

\section{In-gel nuclease assay}

An in-gel DNase assay was performed according to Thelen and Northcote [21], with modifications [22]. For ingel DNase assay, C. cava tuber extracts or fractions after purification were dissolved in SDS-PAGE sample buffer without a reducing agent, incubated at $37^{\circ} \mathrm{C}$ for $10 \mathrm{~min}$, and subjected to SDS-PAGE in $10 \%$ polyacrylamide gel containing denatured calf thymus DNA $(40 \mu \mathrm{g} / \mathrm{ml})$. After the electrophoresis and removal of SDS, the gels were washed with reaction buffer $(10 \mathrm{mM}$ Tris- $\mathrm{HCl}, \mathrm{pH}$ 8.0, containing $10 \mathrm{mM} \mathrm{CaCl} 2$ ). DNase activity was visualized by staining the gel with ethidium bromide.

\section{Cell culture and viability assay}

HeLa cells were cultured in RPMI 1640 supplemented with $5 \%$ FCS, $2 \mathrm{mmol} / \mathrm{l} \mathrm{L}$-glutamine, $100 \mu \mathrm{g} / \mathrm{ml}$ streptomycin and $100 \mathrm{U} / \mathrm{ml}$ penicillin. Viability of cell cultures was appraised using XTT colorimetric test, based on a dynamics of XTT (tetrazoline 2,3-bis(2-methoxy-4nitro-5-sulfofenylo)-2H-5-carboxyanilide) stain reduction by viable cells with the formation of a colored product. Intensity of the fluorescence was measured at the wavelength of $450 \mathrm{~nm}$. Percentage of mitochondrial metabolism activity inhibition was calculated according to the following equation: 100-(OD drug treated cells - OD medium alone/OD untreated cells-OD medium alone*100). Each experiment was conducted independently in 8 cultures and in each culture at least 200 cells were scored. Statistical analysis of the results 
involved the $t$-test for unpaired data using the STATISTICA ver.6.1 software. $P$ value $<0.05$ was considered to represent threshold of significance.

\section{LC-ESI-MS/MS analysis}

Stained protein bands were excised from the gel and analyzed by liquid chromatography coupled to mass spectrometer in the Laboratory of Mass Spectrometry, Institute of Biochemistry and Biophysics, Polish Academy of Sciences, Warsaw, Poland. Samples were concentrated and desalted on RP-C18 precolumn (LC Packings, UK) and further peptide separation was achieved in a nano-HPLC RP-C18 column (LC Packings, $75 \mathrm{mM}$ i.d.) of a UltiMate nano-HPLC system, using a 50-min linear acetonitrile gradient. Column outlet was directly coupled to Finningan Nanospray ion source of LTQ-FT (Thermo, USA) mass spectrometer working in the regime of data dependent MS to MS/MS switch. An electrospray voltage of $1500 \mathrm{~V}$ and a cone voltage of $30 \mathrm{~V}$ were used.

\section{MS/MS data analysis}

The data were analysed automatically by database matching against the NCBInr protein database (NCBI, Bethesda, USA) with a Viridiplantae filter, using the MASCOT database search engine (Matrix science, London, UK; http://www.matrixscience.com) [23].

\section{Results}

Isolation and purification of proteins from Corydalis cava tuber extracts on a heparin column

In order to evaluate if biological activity of Corydalis tuber extracts is related to the proteins contained in them, the proteins of nucleolytic activity were isolated from the tubers by purification on a HT Heparin column (Figure 1A) using ÄKTA Explorer ${ }^{\mathrm{mm}}$ chromatographic system (Amersham Biosciences). Following the application of the extract to the column $(0.7 \times 2.5 \mathrm{~cm})$, molecules which did not bind to the column were eluted using elution buffer (buffer A: $100 \mathrm{mM}$ Tris, $\mathrm{pH}$ $8.0,10 \%$ glycerol). The first eight fractions of $1.5 \mathrm{ml}$ each represented the flow-through fractions. The subsequent fractions were eluted using a linear gradient of $\mathrm{NaCl}$ (from 0 to $2 \mathrm{M}$ ) (19 fractions of $1 \mathrm{ml}$ each). In all the fractions, absorbance was measured at $280 \mathrm{~nm}$ (Figure 1A), indicating the presence of purified proteins in fractions 16-18. Protein fractions purified on heparin column were tested for DNase activity using in-gel DNase assay (Figure 1B) according to Thelen and Northcote [21]. Nucleolytic activity was demonstrated in fraction numbers 16, 17 and 18. All the fractions were also separated in SDS-containing polyacrylamide gel (SDS-PAGE), which was stained with silver according to Shevchenko et al. [20] (Figure 1C). Fraction numbers 16 and 17 each contained five protein bands of molecular weights (MW) approx. 30, 32, 35, 38 and $68 \mathrm{kDa}$, while the fraction number 18 contained an additional fraction of MW around $140 \mathrm{kDa}$.

\section{Analysis of mitochondrial activity of HeLa cells}

All the fractions with nuclease activity were tested for cytotoxic activity in human cervical carcinoma HeLa cells. For the analysis, proteins contained in fraction numbers 16, 17, 18 and 19 were used, from three different rounds of purification. The buffer used for tuber extract isolation $(0.1 \mathrm{M}$ Tris, $10 \%$ glycerol), at the concentration of $26.7 \mu \mathrm{l} / \mathrm{ml}$ served as a negative control. For each fraction, $48 \mathrm{~h}$ cultures of HeLa cells were conducted in the presence of three protein concentrations: 42,83 and $167 \mathrm{ng} / \mathrm{ml}$ from three purification rounds. HeLa cells on the plates were subjected to the action of $\mathrm{XTT} / \mathrm{PBS}$ solution $(1 \mathrm{mg} \mathrm{XTT} / \mathrm{ml}$ in PBS $+1.53 \mathrm{mg}$ $\mathrm{PMS} / \mathrm{ml}$ in PBS) in order to estimate cell viability. Following incubation, the results were recorded using a small plate ELISA reader (Labsystems Multiskan MCC/ 340) with readout at $450 \mathrm{~nm}$. The results are presented in Table 1.

The cytotoxic effect of studied proteins in relation to HeLa cell line was clearly marked and it depended on the applied dose of protein: the most pronounced effect was obtained with protein fractions administered at the highest concentration $(167 \mathrm{ng} / \mathrm{ml})$, while at the intermediate concentration $(83 \mathrm{ng} / \mathrm{ml})$, the effect was appropriately lower compared to the highest concentration. Fraction 18 exerted the highest cytotoxic effect at the concentration of $167 \mathrm{ng} / \mathrm{ml}: 43.45 \pm 3 \%$ cells underwent mitochondrial activity inhibition (Table 1). Protein fractions at the lowest protein concentration $(42 \mathrm{ng} / \mathrm{ml})$ manifested the least pronounced cytotoxic effect (e.g., fraction 16: $4.55 \pm 3.5 \%$, table 1 ). In the experiments, the control was provided by the pure elution buffer (0.1 M Tris, $10 \%$ glycerol), added to HeLa cells at the concentration of $26.7 \mu \mathrm{l} / \mathrm{ml}$, which did not exert any effect on mitochondrial activity of HeLa cells.

\section{Identification of proteins in purified fractions by mass spectrometry}

The protein bands were numbered 1 to 6 (Figure 1C), excised from the gel stained with silver [20] and sent for identification by mass spectrometry (LC-ESI-MS/MS) at the Laboratory of Mass Spectrometry, Institute of Biochemistry and Biophysics, Polish Academy of Sciences (IBB PAN) in Warsaw, Poland. The data was analyzed using MASCOT (http://www.matrixscience.com).

Results of protein identification using tandem mass spectrometry analysis (LC-ESI-MS/MS) are presented in Table 2. It contains a list of identified proteins from fractions of Corydalis cava tuber extracts. Results of 
A

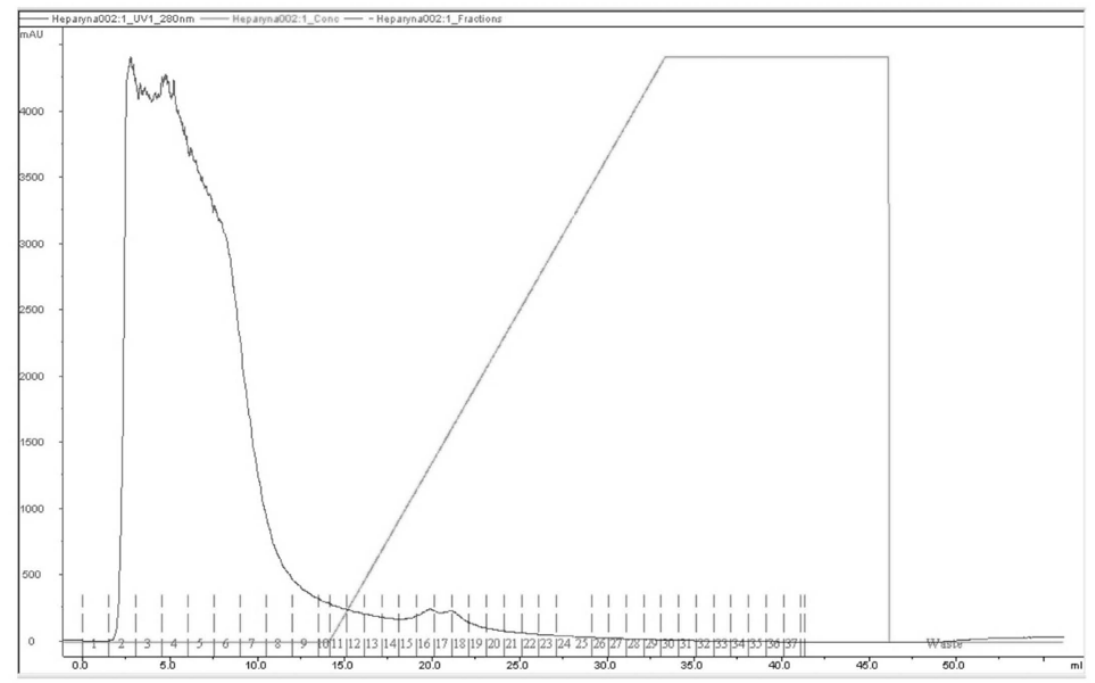

B

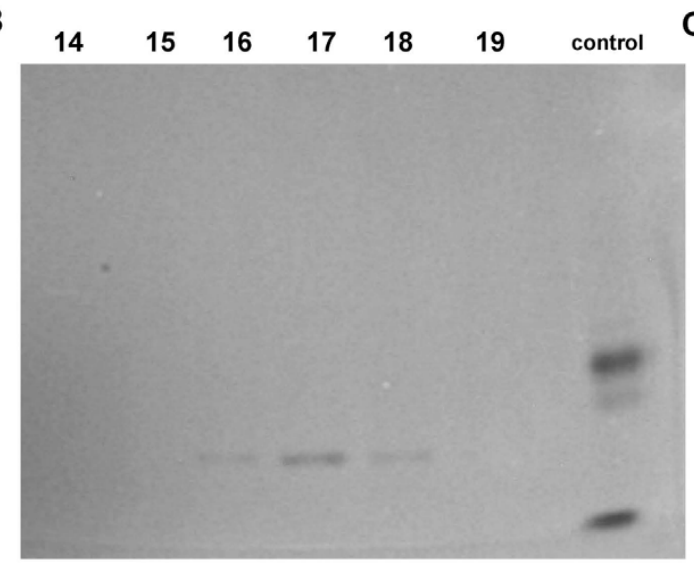

C

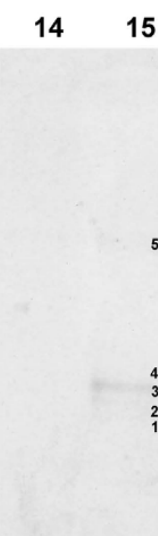

17

18

19

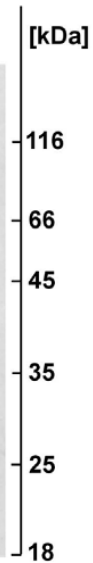

Figure 1 Protein purification and electrophoretic analysis. (A) Chromatographic profile of protein purification from C. cava tuber extracts in HT Heparin column (GE Healthcare). Fractions 1 to 9 represented flow-through fractions, 10 to 27 were eluted with a linear $\mathrm{NaCl}$ gradient (from 0 to $2 \mathrm{M}$ ). The absorbance of all fractions was measured at $280 \mathrm{~nm}$ and their DNase activity was estimated using in-gel assay. Proteins present in fractions 16, 17 and 18 were identified using LC-ESI-MS/MS. Fractions 16-19 following three rounds of purification were used in tests on HeLa tumour cell line. (B) In-gel DNase pattern of the gel in which DNase activity of protein fractions originating from C. cava tuber extracts was estimated. ssDNA containing 10\% SDS-PAGE, following electrophoresis and incubation (12 h) in $10 \mathrm{mM} \mathrm{Ca}{ }^{2+}$ buffer, pH 8.0, was stained with ethidium bromide and viewed under UV light. Nucleolytic activity was noted in fractions Nos.16, 17 and 18 of MW around $30 \mathrm{kDa}$. Control: purified nucleases from Chelidonium majus milky sap served as positive control. (C) 10\% SDS-PAGE following electrophoresis of fractioncontained proteins and silver staining according to Shevchenko et al. [20]. The separated fractions were identical to those in the gel in Fig. 1B. Fractions nos. 16 and 17 each contained 5 protein bands of MW around 30, 32, 35, 38 and 68 kDa, while fraction no. 18 contained an additional band of MW around $140 \mathrm{kDa}$. The protein bands were numbered 1-6, excised from the gel and sent for identification by mass spectrometry (LCESI-MS/MS). M - Protein Molecular Weight Marker (Fermentas).

the identification show that proteins contained in bands of fraction numbers 16-18 belong to plant pathogenesis- (PR) and defense-related proteins. Most of the identified proteins is directly or indirectly involved in defense reactions of the plant against various stresses, e.g. against attack of a pathogen (Table 2).

Analysis of DNase activity has demonstrated the presence of a band with nucleolytic activity in fractions 16, 17 and 18 of molecular weight around $30 \mathrm{kDa}$ (Figure 1B).
Comparison of SDS-PAGE gel following the separation of the same fractions and staining with the silver method (Figure 1C), demonstrates an analogous band of around $30 \mathrm{kDa}$ molecular weight (No. 1) identified as DNA-binding protein from Zea mays with a very similar molecular weight of $27.6 \mathrm{kDa}$ (Table 2). Thus, the studied fraction contains a number of proteins with defense and metabolic significance for the plant.

Table 2 lists identified defense-related proteins with plant species in which the proteins were detected as well 
Table 1 Mitochondrial activity inhibition in neoplastic HeLa cells under the effect of purified protein fractions from extracts of $C$. cava tubers.

\begin{tabular}{cccc}
\hline $\begin{array}{c}\text { Fraction } \\
\text { no. }\end{array}$ & $\begin{array}{c}\text { Protein } \\
\text { concentration } \\
\text { [ng/ml] }\end{array}$ & $\begin{array}{c}\text { Mean value of HeLa } \\
\text { cells inhibition [\%] }\end{array}$ & $\begin{array}{c}\text { Standard } \\
\text { deviation [\%] }\end{array}$ \\
\hline 16 & 42 & 4.55 & 3.53 \\
16 & 83 & 15.57 & 2.42 \\
16 & 167 & 35.31 & 4.32 \\
\hline 17 & 42 & 8.66 & 5.19 \\
17 & 83 & 22.35 & 2.40 \\
17 & 167 & 39.15 & 3.34 \\
\hline 18 & 42 & 12.59 & 5.37 \\
18 & 83 & 32.42 & 3.13 \\
18 & 167 & 43.45 & 3.06 \\
\hline 19 & 42 & 5.90 & 5.43 \\
19 & 83 & 15.18 & 7.10 \\
19 & 167 & 21.78 & 6.06 \\
\hline
\end{tabular}

Proteins from three rounds of purification were administered at concentrations of $42 ; 83$; and $167 \mathrm{ng} / \mathrm{ml}$. The data was analyzed using STATISTICA (version 6.1) software. [\%] - inhibition of mitochondrial activity of HeLa cells under effect of examined proteins as compared to the control. as protein scores and sequence coverages. The number of compatible peptides for individual results ranged between 1 and 43, sequence coverage in a single case reached the maximum value of $26 \%$. In the Table 2 , numbers of protein bands were indicated in which particular proteins were identified (Figure 1C).

\section{Discussion}

Plants that belong to family Papaveraceae, like Greater Celandine (Chelidonium majus L.) and Corydalis cava Schweigg. \& Koerte, are a rich source of various biologically active substances with strong pharmacological activity. The mechanism of this activity is still unknown, but very important compounds are the proteins contained in the plants. Our earlier studies showed that biological activity of Chelidonium majus milky sap may be related to its protein content. The protein fractions which contained two nucleases induced apoptosis in human cervical cancer HeLa cells [17].

Most probably, the present study represents the first investigations on the effect of purified PR proteins from

Table 2 Defense-related proteins identified in fractions after purification of nucleases from extracts of Corydalis cava tubers using LC-ESI-MS/MS.

\begin{tabular}{|c|c|c|c|c|c|c|c|}
\hline $\begin{array}{l}\text { No. of protein } \\
\text { band }^{\text {a) }}\end{array}$ & Identified protein ${ }^{\mathbf{b})}$ & $\begin{array}{l}\text { Accesion } \\
\text { No. }^{c)}\end{array}$ & $\begin{array}{l}\text { Matched } \\
\text { peptides }^{\text {d) }}\end{array}$ & Score $^{\mathrm{e})}$ & $\begin{array}{l}\text { Mol. mass } \\
\left.(\mathrm{Da})^{\mathrm{f}}\right)\end{array}$ & $\mathrm{p} / \mathrm{g})$ & $\begin{array}{l}\text { Sequence } \\
\text { coverage }(\%)^{h)}\end{array}$ \\
\hline $1,2,3,4$ & peroxidase [Nicotiana tabacum] (PR-9) & $\begin{array}{l}\text { gil } \\
14031049\end{array}$ & 16 & 560 & 39495 & 5.99 & 13 \\
\hline 5,6 & heat shock protein 70 [Chlorella zofingiensis] & $\begin{array}{l}\text { gil } \\
18482472\end{array}$ & 4 & 180 & 70112 & 8.29 & 8 \\
\hline 1 & pectinesterase [Phaseolus vulgaris] & gi|21060 & 2 & 112 & 23967 & 9.52 & 4 \\
\hline 2 & $\begin{array}{l}\text { SODP_PETHY Superoxide dismutase (ISS) } \\
\text { [Ostreococcus tauri] }\end{array}$ & $\begin{array}{l}\text { gi| } \\
116056311\end{array}$ & 2 & 74 & 42244 & 11.68 & 4 \\
\hline 4 & GRP-like protein 2 [Gossypium hirsutum] & $\begin{array}{l}\text { gil } \\
110559491\end{array}$ & 3 & 69 & 41333 & 6.01 & 8 \\
\hline 5 & $\begin{array}{l}\text { disease resistance protein (TIR-NBS-LRR class), } \\
\text { putative [Arabidopsis thaliana] }\end{array}$ & $\begin{array}{l}\text { gil } \\
15229962\end{array}$ & 1 & 64 & 117364 & 7.49 & 0 \\
\hline 3 & ribosomal protein S12 [Mesostigma viride] & $\begin{array}{l}\text { gil } \\
11466414\end{array}$ & 1 & 55 & 13815 & 11.32 & 9 \\
\hline 1 & DNA-binding protein [Zea mays] & $\begin{array}{l}\text { gi| } \\
195658581\end{array}$ & 1 & 54 & 27597 & 6.49 & 4 \\
\hline 4 & $\begin{array}{l}\text { chloroplast nucleoid DNA-binding protein-related } \\
\text { [Arabidopsis thaliana] }\end{array}$ & $\begin{array}{l}\text { gil } \\
18391062\end{array}$ & 1 & 53 & 48429 & 7.48 & 2 \\
\hline 4 & RPP13-like protein [Arabidopsis arenosa] & $\begin{array}{l}\text { gil } \\
46410122\end{array}$ & 1 & 52 & 70976 & 5.51 & 2 \\
\hline
\end{tabular}

a) Assigned numbers of protein bands as indicated in Fig. 1C.

b) Identified homologous proteins and organism from which it proceeds.

c) Database accession numbers according to: NCBInr (nr); trEMBL (trm).

d) Number of matched peptides with Mascot Search data (http://www.matrixscience.com).

e) Mascot Search Probability Based Mowse Score. lons score is $-10^{*} \log (P)$, where $P$ is the probability that the observed match is a random event. Individual ions scores $>48$ indicate identity or extensive homology $(p<0.05)$.

f) Theoretical mass $(\mathrm{kDa})$ of identified proteins. The values were retrieved from the protein database.

g) Theoretical pl of identified proteins. The values were retrieved from the protein database.

h) Amino acid sequence coverage for the identified proteins. 
tuber extracts of a pharmacologically active plant on cell lines. The cytotoxic effect of studied proteins toward HeLa cell line cells has been evident and dependent on increasing dose of the protein.

Results of protein identification in fractions from purification of C. cava tuber extracts using LC-ESI-MS/MS analysis have shown that proteins contained in bands of fractions 16-18 belong to plant pathogenesis- and defense-related proteins, indirectly or directly involved in plant defense reactions against stresses of various kind. Many of them belong to the PR protein family involved in plant defense against the pathogen attack. The family includes 17 protein classes of variable activities [24]. C. cava tubers are exposed to the attack of fungal, viral, bacterial and other pathogens during the entire vegetation season as well as during winter time [25]. Accumulation of high number and variability of defense proteins in tubers together with several secondary metabolites, such as isoquinoline alkaloids, provides an effective and long-time protection against attack of pathogens. Moreover, defense-related proteins contained in C. cava tubers resemble 21 proteins identified earlier by our group in Chelidonium majus milky sap [15].

The studies represent preliminary demonstration of the effect exerted by tuber proteins from a plant of pharmacological significance on cells of a tumour cell line. The investigated protein fractions comprise a mixture of plant defense-related proteins. In subsequent studies, an effort will be made to isolate the individual proteins and examine their effect on tumour cells individually and in combinations as well. Nevertheless, the synergistic action of all the compounds present in plant protein extracts is very important for their activity. Many effective and extensively studied compounds of plant origin are, in fact, crude protein mixtures, such as phytotherapeutical drug bromelain, which is crude, aqueous extract from the stems and immature fruits of pineapples (Ananas comosus from the family Bromeliaceae), constituting a complex mixture of different thiol-endopeptidases and other components such as phosphatases, glucosidases, peroxidases, cellulases, glycoproteins, carbohydrates and several proteinase inhibitors [26]. Also, Viscum album L. extracts (VAE, European mistletoe) are composed of pharmacologically relevant compounds like: mistletoe lectins (ML I, II and III), viscotoxins and other low molecular proteins, VisalbCBA (Viscum album chitin-binding agglutinin), oligo- and polysaccharides, flavonoids, vesicles, triterpene acids, and others. Whole VAE as well as several of the compounds are cytotoxic and the mistletoe lectins have strong apoptosis-inducing effects [27].

Although the mechanism of presented activity of C. cava proteins is unknown, their defensive role for the plant could be very important. Many plant defense-related proteins belong to small (14-40 amino acids), linear, cationic peptides. These peptides have membrane lytic properties and potent activity against a broad spectrum of microorganisms. They organize into ordered secondary structures ( $\alpha$-helix and $\beta$-sheet) in the membrane [28]. Above a threshold concentration, peptides disturb the cell membrane and cause cell death due to membrane disintegration [29].

\section{Conclusions}

Presented studies confirm that biological activity of $C$. cava extracts may also be related to proteins contained in the extracts. For possible further applications, the biologically active plant proteins should be separated from alkaloids and other secondary metabolites, which in higher doses might be toxic [14]. The studies represent preliminary demonstration of the effect exerted by tuber proteins from a plant of pharmacological significance on cells of a tumour cell line. In the subsequent studies, an effort will be made to isolate the individual proteins and examine their effect on tumour cells individually and in combinations.

\section{Acknowledgements}

This work was financed by the AMU-UMS-ULS inter-universities grant no. 512-00-073 (2009, Poznań, Poland) and Polish Minister of Science and Higher Education grant no. 0872/B/P01/2008/34

\section{Author details}

${ }^{1}$ Department of Molecular Virology, Institute of Experimental Biology, Faculty of Biology, Adam Mickiewicz University, Umultowska 89, 61-614 Poznan, Poland. 'Department of Cell Biology, University of Medical Sciences, Rokietnicka 5d, 60-806 Poznan, Poland. ${ }^{3}$ Department of Biotechnology and Food Microbiology, Poznan University of Life Sciences, Wojska Polskiego 48, 60-627 Poznan, Poland. ${ }^{4}$ Department of Plant Ecology and Environment Protection, Institute of Environmental Biology, Faculty of Biology, Adam Mickiewicz University, Umultowska 89, 61-614 Poznan, Poland.

\section{Authors' contributions}

RN: Performed the study, collected plant material, evaluated the MS/MS data and prepared the manuscript; MWC: Carried out the study on cell lines, performed the statistical analysis and helped to draft the manuscript; WB: Isolated and purified proteins from plant extracts on a heparin column; DW: Participated in protein isolation and purification and in cell line analyses, helped in MS/MS data analysis; SB: Participated in design and coordination of the study, helped to collect the plant material; AGJ: Supervised the work, participated in its design and coordination and corrected the manuscript for publication. All the authors have approved the final manuscript.

\section{Competing interests}

The authors declare that they have no competing interests.

Received: 5 June 2010 Accepted: 17 December 2010

Published: 17 December 2010

\section{References}

1. Cronquist A: An Integrated System of Classification of Flowering Plants New York, Columbia University Press; 1981.

2. Reveal JL: System of Classification. PBIO 250 Lecture Notes: Plant Taxonomy Department of Plant Biology, University of Maryland; 1999.

3. Colombo ML, Bosisio E: Pharmacological activities of Chelidonium majus L. (Papaveraceae). Pharm Res 1996, 33:127-134. 
4. Rueffer M, Bauer W, Zenk MH: The formation of corydaline and related alkaloids in Corydalis cava in vivo and in vitro. Can J Chem 1994, 72:170-175.

5. Hänsel R, Sticher O: Pharmakognosie-Phytopharmazie. Heidelberg, Springer Verlag; 2004.

6. Freudenreich $\mathrm{O}$ : Ocular side effects associated with dietary supplements and herbal medicines. Drugs Today 2005, 41:537.

7. Cheng ZH, Guo Y-L, Wang H-Y, Chen G-Q: Qualitative and quantitative analysis of quaternary ammonium alkaloids from Rhizoma Corydalis by matrix-assisted laser desorption/ionization Fourier transform mass spectrometry coupled with a selective precipitation reaction using Reinecke salt. Anal Chim Acta 2006, 555:269-277.

8. Gao JL, Shi JM, He K, Zhang QW, Li SP, Lee SM, Wang YT: Yanhusuo extract inhibits metastasis of breast cancer cells by modulating mitogen-activated protein kinase signaling pathways. Oncol Rep 2008, 20:819-824.

9. An HJ, Rim HK, Chung HS, Choi IY, Kim NH, Kim SJ, Moon PD, Myung NY, Jeong HJ, Jeong $\mathrm{CH}$, Chung SH, Um JY, Hong SH, Kim HM: Expression of inducible nitric oxide synthase by Corydalis turtschaninovii on interferongamma stimulated macrophages. J Ethnopharmacol 2009, 122:573-578.

10. Schäfer HL, Schäfer H, Schneider W, Elstner EF: Sedative action of extract combinations of Eschscholtzia californica and Corydalis cava. Arzneimittelforschung 1995, 45:124-126.

11. Adsersen A, Kjølbye A, Dall O, Jäger AK: Acetylcholinesterase and butyrylcholinesterase inhibitory compounds from Corydalis cava Schweigg. \& Kort. J Ethnopharmacol 2007, 113:179-182.

12. Tome F, Colombo ML: Distribution of alkaloids in Chelidonium majus and factors affecting their accumulation. Phytochemistry 1995, 40:37-39.

13. Benninger J, Schneider HT, Schuppan D, Kirchner T, Hahn EG: Acute hepatitis induced by greater celandine (Chelidonium majus). Gastroenterology 1999, 117:1234-1237.

14. Stickel F, Pöschl G, Seitz HK, Waldherr R, Hahn EG, Schuppan D: Acute hepatitis induced by Greater Celandine (Chelidonium majus). Scand J Gastroenterol 2003, 38:565-568

15. Nawrot R, Kalinowski A, Gozdzicka-Jozefiak A: Proteomic analysis of Chelidonium majus milky sap using two-dimensional gel electrophoresis and tandem mass spectrometry. Phytochemistry 2007, 68:1612-1622.

16. Nawrot R, Lesniewicz K, Pienkowska J, Gozdzicka-Jozefiak A: A novel extracellular peroxidase and nucleases from a milky sap of Chelidonium majus L. Fitoterapia 2007, 78:496-501.

17. Nawrot R, Wołuń-Cholewa M, Goździcka-Józefiak A: Nucleases isolated from Chelidonium majus L. milky sap can induce apoptosis in human cervical carcinoma HeLa cells but not in Chinese Hamster Ovary CHO cells. Folia Histochem Cytobiol 2008, 46:79-83.

18. Lowry OH, Rosebrough NJ, Farr AL, Randall RJ: Protein measurement with the Folin phenol reagent. J Biol Chem 1951, 193:265-275.

19. Laemmli UK: Cleavage of structural proteins during the assembly of the head of bacteriophage T4. Nature 1970, 227:680-685.

20. Shevchenko A, Wilm M, Vorm O, Mann M: Mass spectrometric sequencing of proteins silver-stained polyacrylamide gels. Anal Chem 1996, 68:850-858.

21. Thelen MP, Northcote DH: Identification and purification of a nuclease from Zinnia elegans L.: a potential molecular marker for xylogenesis. Planta 1989, 179:181-195.

22. Ito J, Fukuda H: ZEN1 is a key enzyme in the degradation of nuclear DNA during programmed cell death of tracheary elements. Plant Cell 2002, 14:3201-3211.

23. Perkins DN, Pappin DJ, Creasy DM, Cottrell JS: Probability-based protein identification by searching sequence databases using mass spectrometry data. Electrophoresis 1999, 20:3551-3567.

24. Sels J, Mathys J, De Coninck BM, Cammue BP, De Bolle MF: Plant pathogenesis-related (PR) proteins: a focus on PR peptides. Plant Physiol Biochem 2008, 46:941-950.

25. Olesen JM, Ehlers BK: Age determination of individuals of Corydalis species and other perennial herbs. Nord J Bot 2008, 21:187-194.

26. Maurer HR: Bromelain: biochemistry, pharmacology and medical use. Cell Mol Life Sci 2001, 58:1234-1245.

27. Kienle GS, Glockmann A, Schink M, Kiene H: Viscum album L. extracts in breast and gynaecological cancers: a systematic review of clinical and preclinical research. J Exp Clin Cancer Res 2009, 28:79.
28. Zhong J, Chau Y: Antitumor activity of a membrane lytic peptide cyclized with a linker sensitive to membrane type 1-matrix metalloproteinase. Mol Cancer Ther 2008, 7:2933-2940.

29. Shai Y: Mode of action of membrane active antimicrobial peptides. Biopolymers 2002, 66:236-248.

\section{Pre-publication history}

The pre-publication history for this paper can be accessed here: http://www.biomedcentral.com/1472-6882/10/78/prepub

doi:10.1186/1472-6882-10-78

Cite this article as: Nawrot et al: Cytotoxic activity of proteins isolated from extracts of Corydalis cava tubers in human cervical carcinoma HeLa cells. BMC Complementary and Alternative Medicine 2010 10:78.

\section{Submit your next manuscript to BioMed Central and take full advantage of:}

- Convenient online submission

- Thorough peer review

- No space constraints or color figure charges

- Immediate publication on acceptance

- Inclusion in PubMed, CAS, Scopus and Google Scholar

- Research which is freely available for redistribution

Submit your manuscript at www.biomedcentral.com/submit
C Biomed Central 